\title{
Koululaitoksen sisäinen uudistuminen on todellisen jatkuvan koulutuksen edellytys
}

\section{Tavoitteeksi toiminta- koulu}

Koulun uudistamisen voisi vähitellen alkaa. Tähänastiset toimenpiteet ovat olleet uudistumisen ulkoisten puitteiden rakentamista. Niiden tuloksena meillä onkin saatu valmiiksi selkeä luonnonmukainen koulutusjärjestelmä ja rakennettu riittävästi koulutiloja sekä uudistettu opettajainkoulutus.

Uudet koululait merkitsevät päätepistettä puitteiden rakentamiselle ja lähtölaukausta sisäiselle uudistukselle. Uudistusta pitkään rasittanut hallintokiistely loppui eduskunnan yksimieliseen päätökseen ja ovet avattiin koulun pedagogiselle kehittämiselle. Ellei sisäisen uudistuksen välttämättömyyttä nyt tajuta jäävät koululakien hyvät tarkoitukset toteutumatta.

Koulun sisäisessä uudista- misessa on tajuttava koulu ihmisen jatkuvan kehitysprosessin osaksi, mikä prosessi kylläkin tapahtuu muilta oppimisena, mutta aina oman toiminnan kautta. Koulu perusongelmana on edelleen oppimisen irroittaminen luonnollisista yhteyksistään. Tähän perusongelmaan kietoutuu myös koulun yhteiskunnallinen ongelma, sillä yhteyksistään irroitetun oppimisen haittoja on aina helpompi torjua henkisesti ja aineellisesti hyvinvoivan kodin keinoin. Koulun sisäinen uudistaminen toimintakoulun suuntaan on siis sekä koulun sivistyksellisen että siihen liittyvän yhteiskunnallisen tehtävän mukaista.

Toimintakoulu tarkoittaa kaiken opetuksen ja myös koulun sosiaalisen yhteiselämän järjestämistä oppilaiden luontaisen toiminnallisuuden perustalle. Kysymys on paljon työkoulua laajemmasta uudistuksesta, jonka yhteydessä "'teoreettisen ja käytännöllisen" käsitteet on ajateltava kokonaan uudelleen.

Jatkuvalle koulutukselle vasta toimintakouluun siirtyminen luo todelliset edellytykset. Peruskoulu ja keskiasteen koulutus ovat jatkuvan koulutuksen osia, joissa luodaan valmiudet jatkuvaan itsensä kehittämiseen. Oppimisen liittäminen luontaiseen toiminnallisuuteen avaa ihmiselle uuden suhteen itseensä ja ympäristöönsä. Samalla se avaa hänelle mahdollisuudet jatkuvaan itsensä kehittämiseen aktiivisen opiskelun kautta.

Jatkuvan koulutuksen toteuttaminen alkaa siis koulusta eikä suinkaan sen ulkopuolelta jostain erillisestä aikuiskoulutuksesta. Näin päin edeten uudistuvat sekä koulu että aikuiskoulutus. 